\title{
MORPHOGENETIC AND STRUCTURAL CHARACTERISTICS OF ALEXANDERGRASS PASTURES UNDER CONTINUOUS STOCKING
}

\section{CARACTERÍSTICAS MORFOGÊNICAS E ESTRUTURAIS DE PASTOS DE PAPUA MANEJADOS SOB LOTAÇÃO CONTÍNUA}

\author{
Francisco Migliorini ${ }^{1}$ \\ André Brugnara Soares ${ }^{1}$ \\ Daniel Schmitt ${ }^{1^{*}}$ \\ Laíse da Silveira Pontes ${ }^{2}$ \\ Tangriani Simioni Assmann ${ }^{1}$ \\ ${ }^{1}$ Federal University of Technology of Paraná (UTFPR), Pato Branco, PR, Brazil. \\ ${ }^{2}$ Agricultural Research Institute of Paraná (IAPAR), Ponta Grossa, PR, Brazil. \\ *Corresponding author - daniel.schmitt@veterinario.med.br
}

\begin{abstract}
The aim of this study was to evaluate some morphogenetic and structural characteristics to explain variations in forage accumulation of Alexandergrass (Urochloa (Syn. Brachiaria) plantaginea) under continuous stocking method. The experimental treatments consisted of four grazing heights $(10,20$, 30 , and $40 \mathrm{~cm}$ ), allocated to experimental units following a randomized block design with three replicates. The following variables were analyzed: leaf appearance, elongation, and senescence rates, leaf lamina length, number of leaves per tiller, leaf area index (LAI), and forage accumulation rate. Data were submitted to analysis of variance and means were compared by Student's $t$-test $(\mathrm{P} \leq 0.05)$. The main results were: i) different grazing heights had different tissue flows; ii) grazing heights between 30-40 $\mathrm{cm}$ showed the highest LAI, and produced similar values; iii) forage accumulation rate increased according to grazing height increments, but did not change above $30 \mathrm{~cm}$. In conclusion, Alexandergrass pastures under continuous stocking should not be maintained at grazing heights lower than $30 \mathrm{~cm}$ if the objective is to maximize forage production.
\end{abstract}

Keywords: tissue flow; forage production; grazing intensity; integrated crop-livestock systems.

\section{Resumo}

O objetivo deste trabalho foi avaliar alguns aspectos morfogênicos e estruturais para explicar eventuais alterações no acúmulo de forragem de pastos de papuã (Urochloa (Syn. Brachiaria) plantaginea) sob lotação contínua. Os tratamentos experimentais corresponderam a quatros alturas de dossel $(10,20,30$ e $40 \mathrm{~cm})$, alocados às unidades experimentais conforme um delineamento de blocos completos casualisados, com três repetições. As variáveis analisadas foram: taxa de alongamento, aparecimento e senescência foliar; densidade populacional de perfilhos; comprimento e número de lâminas foliares por perfilho; índice de área foliar (IAF); taxa de acúmulo de forragem. Os dados foram submetidos à análise de variância e as médias comparadas pelo teste $\mathrm{t}$ de "Student" $(\mathrm{P} \leq 0,05)$. Os principais resultados obtidos foram: i) diferentes alturas de manejo apresentam diferentes ritmos 
de aparecimento, crescimento e morte de tecidos; ii) pastos manejados entre 30-40 cm apresentaram os maiores valores de IAF e foram semelhantes entre si; iii) a taxa de acúmulo aumentou com o aumento da altura de manejo, mas não foi alterada a partir de $30 \mathrm{~cm}$. Recomenda-se manejar pastos de papuã sob lotação contínua com não menos que $30 \mathrm{~cm}$ quando o objetivo for maximizar a produção de forragem.

Palavras-chave: fluxo de tecidos; produção de forragem; intensidade de pastejo; sistemas integrados de produção agropecuária.

Received on: December 22, 2017.

Accepted on: July 5, 2018.

\section{Introduction}

Urochloa (Syn. Brachiaria) plantaginea, popularly known as Alexandergrass, is an annual warmseason grass that appears spontaneously in grain crop fields during warm periods of the year. In areas intended for integrated crop-livestock systems (ICLS), Alexandergrass can be a low-cost forage alternative, as it has a high potential for natural reseeding, and benefits from cultural practices (e.g., fertilization) that were performed in previous crops. Additionally, because it is present in large quantities at the end of the summer cropping season, it can be considered as a fodder alternative during the feed shortage period in the fall(1).

Despite the advantages of ICLS, such species are not widely used. A possible explanation may be the lack of effective management targets for the creation and maintenance of structures that maximize forage production. In fact, most of the traditional management targets (e.g., fixed stocking rate, grazing pressure) favor harvest efficiency and do not control sward canopy structure, which in turn penalize forage accumulation ${ }^{(2)}$. In this context, setting targets for grazing height can be an effective tool for the production of forage in quantity and quality, as this has been shown to be an integrative variable, relating to several processes that occur at sward canopy level ${ }^{(2-3)}$.

Pastures under continuous stocking method have to maintain a specific range of grazing heights to obtain a high productive potential ${ }^{(2-3)}$. This is the result of compensatory effects between tissue flow (g/tiller/day) and tiller population density (tillers $\left./ \mathrm{m}^{2}\right)^{(4-5)}$. Although the explanatory bases are well established, the scientific literature contains no conclusive evidence concerning optimal management targets for Alexandergrass pastures. Against this background, the aim of this trial was to evaluate the morphogenesis, structural characteristics, and herbage accumulation of continuously stocked Alexandergrass swards maintained at different grazing heights.

\section{Materials and Methods}

The experiment was carried out in Pato Branco/PR, Brazil $\left(25^{\circ} 07^{\prime} \mathrm{S}, 52^{\circ} 41^{\prime} \mathrm{W}\right)$, between January and April 2010. According to the Köppen climate classification, the region has a Cfa-type climate (subtropical). The weather conditions observed during the experimental period are shown in Figure 1. The experimental area has been a non-tillage ICLS for around 20 years, and the cultivation before the experiment was black oats (Avena strigosa Scherb. 'IAPAR 61') intercropped with annual ryegrass 
(Lolium multiflorum Lam. 'São Gabriel'). The Alexandergrass pastures were established by natural reseeding, as the experimental area had a high seed bank remaining from a rest period in the autumn prior to the experiment. On December 10, 2009, the area was mowed in order to reduce vegetation cover, to improve germination of the Alexandergrass seeds.

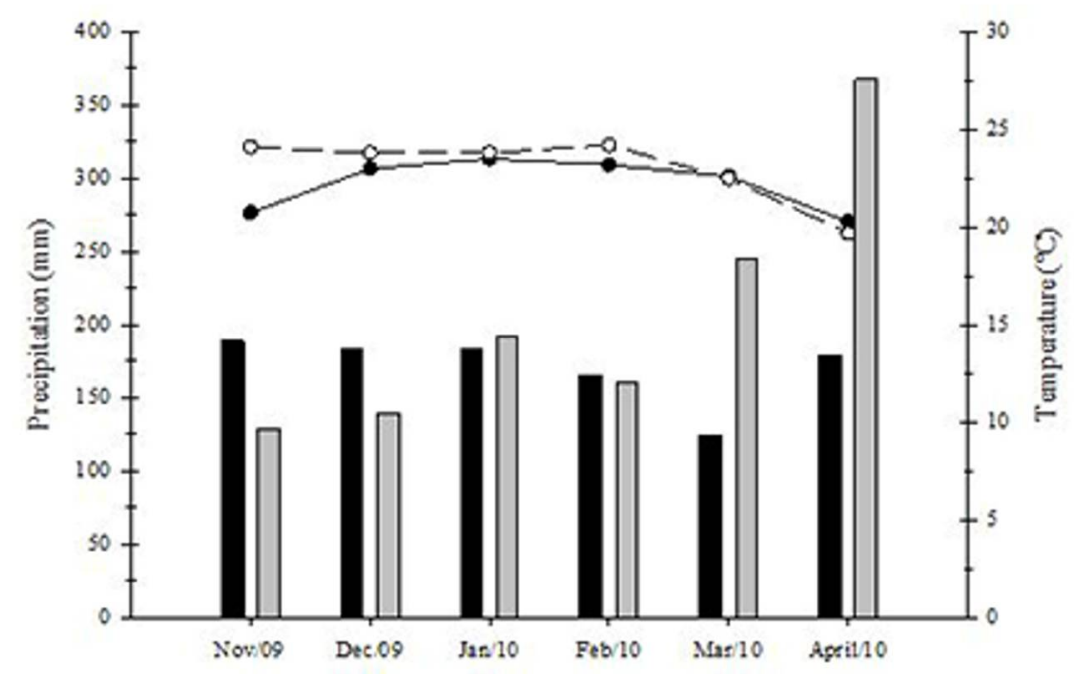

Figure 1. Average monthly temperatures (minimum, mean, and maximum) and rainfall from the experimental year (2009/2010) and the last 40 years in Pato Branco/PR/Brazil. Lines represent the average historical temperatures (dashed) and those during the experimental period (solid). Bars represent the historical monthly precipitation (black) and that from the experimental period (gray). Source: Agricultural Research Institute of Paraná (IAPAR).

The soil at the experimental site is a Red Dystrophic Oxisol with clay texture ${ }^{(6)}$. According to soil analysis performed before the experimental period, the following characteristics were found at a depth of 0-15 cm: $\mathrm{pH}\left(\mathrm{CaCl}_{2}\right), 4.7 ; \mathrm{MO}, 67.2 \mathrm{~g} / \mathrm{dm}^{3} ; \mathrm{P}$ (Mehlich-1), $19.9 \mathrm{mg} / \mathrm{dm}^{3} ; \mathrm{K}, 399.7 \mathrm{cmol}_{\mathrm{c}} / \mathrm{dm}^{3} ; \mathrm{Ca}$, $5.4 \mathrm{cmol}_{\mathrm{c}} / \mathrm{dm}^{3} ; \mathrm{Mg}, 2.7 \mathrm{cmol}_{\mathrm{c}} / \mathrm{dm}^{3} ; \mathrm{H}+\mathrm{Al}, 7.9 \mathrm{cmol}_{\mathrm{c}} / \mathrm{dm}^{3}$; cation exchange capacity (CEC), 16.9 $\mathrm{cmol}_{\mathrm{c}} / \mathrm{dm}^{3}$; and base saturation (V), 52.3\%. Based on these results and the Fertilizing and Liming Manual for the States of Rio Grande do Sul and Santa Catarina ${ }^{(7)}$, fertilization was performed. Nitrogen fertilizer was split-applied in three applications, after observing the rainfall occurrence to ensure maximum assimilation of $\mathrm{N}$ by the pasture. The dates, sources, and amount of $\mathrm{N}$ applied during the experiment were: December 21, 2009, as urea (100 kg N/ha); January 28, 2010, as ammonium nitrate (50 kg N/ha); and March 15, 2010, as urea (50 kg N/ha). Phosphorus fertilization was performed in a single application of $100 \mathrm{~kg} \mathrm{P}_{2} \mathrm{O}_{5} / \mathrm{ha}$ on December 21, 2009, using triple superphosphate.

The experimental treatments corresponded to four grazing heights $(10,20,30$, and $40 \mathrm{~cm})$, maintained by continuous stocking and variable stocking rate ("put-and-take"). The grazing heights were based on studies performed with Brachiaria brizantha 'Marandu' ${ }^{(8)}$, because of their structural similarities and the scarcity of management targets for Alexandergrass pastures. The pastures were grazed by one-year-old Boer goats (Capra aegagrus hircus), with an initial average body weight (LW) of $38 \pm$ $5.3 \mathrm{~kg}$. The mean stocking density $(\mathrm{kg} \mathrm{LW} / \mathrm{ha})$ and observed canopy heights $(\mathrm{cm})$ during the experimental period are shown in Figure 2. 

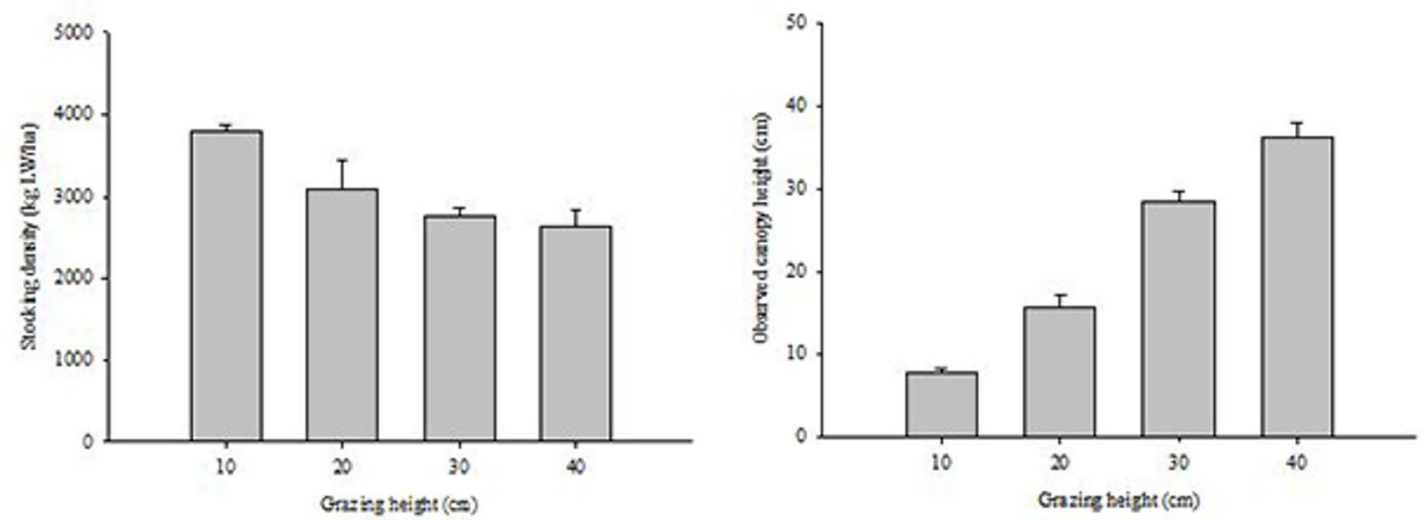

Figure 2. Mean stocking density (left; $\mathrm{kg} \mathrm{LW} / \mathrm{ha}$ ) and observed canopy height (right; $\mathrm{cm}$ ) registered during the experimental period. Vertical error bars correspond to the mean standard error.

Following the mowing performed on December 10, sward surface height was monitored twice per week with a sward stick, at 40 random points per experimental unit. As soon as pastures reached an average height of $30 \mathrm{~cm}$ (December 31, 2009), grazing was initiated, and the stocking rate $(\mathrm{kg} \mathrm{LW} / \mathrm{ha})$ adjusted to establish the intended canopy height targets. On January 6, 2010, the experimental period was initiated.

Morphogenetic and structural characteristics were determined by using the marked-tiller technique ${ }^{(9)}$. For this purpose, 30 tillers per paddock were marked with colored wires, every $40 \mathrm{~cm}$ along two 12 $\mathrm{m}$-long transects. With a ruler, the following readings were taken every two days during two periods (P1: $02 / 02 / 2010$ to $02 / 12 / 2010$; P2: $03 / 05 / 2010$ to $03 / 13 / 2010$ ): extended tiller height (from the ground to the tip of the highest leaf when vertically aligned); stem + pseudostem length (from the ground to the last exposed ligule); and leaf lamina length and width (taken from the median portion). In addition, all leaf laminas were classified as intact or defoliated, fully expanded (with exposed ligule), or expanding (no exposed ligule), and living or senescing (presence or absence of yellow areas). The lengths of the fully expanded leaves were measured from the ligule to the tip, and for expanding leaves (no exposed ligule), the last exposed ligule was taken as a reference. For senescing leaves, only the length of the green portion was considered. Finally, at the beginning of each experimental period (P1 and P2), tiller population density (TPD) was estimated by counting the total number of existing tillers within $0.125 \mathrm{~m}^{2}$ metal quadrats, placed at three random points per pasture.

The forage accumulation rate was estimated by using grazing exclusion cages. For this purpose, in each experimental unit, two circular exclusion cages $(1 \mathrm{~m}$ diameter $\times 1 \mathrm{~m}$ height, with a $50 \times 100 \mathrm{~mm}$ rigid wire mesh) were placed on areas representative of the average pasture condition (visual assessment of herbage mass and height). At the same time, three forage samples outside of the cages were collected close to the ground, using a $0.25 \mathrm{~m}^{2}$ metal quadrats $\left(\mathrm{HM}_{\text {Day0 }}\right)$. At the end of three weeks, the forage mass inside the exclusion cages was collected (HM $\left.\mathrm{H}_{\text {Day21 }}\right)$. Immediately after collection, all samples were dried in a convection oven at $65^{\circ} \mathrm{C}$ for 48 hours and then weighed to estimate dry matter content (\%DM). Finally, based on the difference between forage masses (HMDay21 - $\left.\mathrm{HM}_{\text {Day0 }}\right)$ and the evaluation interval (21 days), the forage accumulation rate was estimated (kg $\mathrm{DM} / \mathrm{ha} /$ day).

The experimental design was a completely randomized block, with three replications, totaling twelve 
experimental units of 0.033-0.059 ha. The data were submitted to analysis of variance using the MIXED procedure (mixed models) of SAS (SAS Institute, Cary, NC, USA). The effects of treatment, period, block, and the treatment*period interaction were considered as fixed. Additionally, period was considered as a repeated-measurement. Treatment means were estimated by LSMEANS and compared by Student's $t$-test (PDIFF). A regression analysis was performed to establish the linear relationship between "leaf area index $\times$ forage accumulation rate", using SigmaPlot (Systat Software Inc., Richmond, CA, USA). The level of significance for all analyses was set at $5 \%(\mathrm{P} \leq 0.05)$.

\section{Results and Discussion}

The leaf appearance rate (LAR) varied according to the evaluation period $(\mathrm{P}=0.0109)$ and the grazing height $(\mathrm{P}=0.0073)$, with no significant interaction between these factors $(\mathrm{P}=0.9124)$. Regardless of the evaluation period, pastures maintained at more than $30 \mathrm{~cm}$ presented a lower LAR, though the 20 $\mathrm{cm}$ treatment was statistically equivalent (Table 1). Such a result can be attributed to the greater leaf sheath tube commonly observed at taller grazing heights, what leads to a delay in the emergence and visualization of subsequently appeared leaves ${ }^{(10)}$. Additionally, regardless of grazing height, greater LARs were detected during the first evaluation period (Table 1), probably as a consequence of more favorable environmental conditions (e.g., temperature, rainfall, and light availability) during that period. The phyllochron (PHY) had the same pattern of response as the LAR (evaluation period, $\mathrm{P}=0.0008$; grazing height, $\mathrm{P}=0.0021$; evaluation period* grazing height, $\mathrm{P}=0.4733$; Table 2). In fact, such a pattern of response was expected, as PHY is obtained from an inverse relationship with LAR $(\mathrm{PHY}=1 / \mathrm{LAR})$. In this way, variations in PHY can be explained in the same terms as LAR.

Table 1. Leaf appearance rate (leaves/day) of Alexandergrass pastures maintained at four grazing heights $(10,20,30$, or $40 \mathrm{~cm})$ by continuous stocking method.

\begin{tabular}{lccccc}
\hline \multirow{2}{*}{ Period } & \multicolumn{4}{c}{ Grazing height $(\mathbf{c m})$} & \multirow{2}{*}{ Mean } \\
\cline { 2 - 5 } & $\mathbf{1 0}$ & $\mathbf{2 0}$ & $\mathbf{3 0}$ & $\mathbf{4 0}$ & \\
\hline $\mathbf{1}$ & 0.23 & 0.20 & 0.14 & 0.15 & $0.18^{\mathrm{A}}$ \\
$\mathbf{2}$ & 0.20 & 0.14 & 0.08 & 0.07 & $0.12^{\mathrm{B}}$ \\
\hline Mean & $0.22^{\mathrm{a}}$ & $0.17^{\mathrm{ab}}$ & $0.11^{\mathrm{b}}$ & $0.11^{\mathrm{b}}$ & \\
\hline
\end{tabular}

Means followed by the same lower-case letters in rows and upper-case letters in columns are not different by Student's $t$-test $(\mathrm{P}>0.05)$. Mean standard errors: period $=0.01$; grazing height $=0.02$. Dates: $\mathrm{P} 1$ (02/02/2010-02/10/2010); P2 (03/05/2010-03/13/2010).

Table 2. Phyllochron (days) of Alexandergrass pastures maintained at four grazing heights $(10,20,30$, or $40 \mathrm{~cm})$ by continuous stocking method.

\begin{tabular}{|c|c|c|c|c|c|}
\hline \multirow{2}{*}{ Period } & \multicolumn{4}{|c|}{ Grazing height $(\mathrm{cm})$} & \multirow{2}{*}{ Mean } \\
\hline & 10 & 20 & 30 & 40 & \\
\hline 1 & 4.3 & 5.0 & 6.9 & 6.7 & $5.6^{\mathrm{B}}$ \\
\hline 2 & 5.4 & 7.6 & 13.5 & 13.5 & $9.3^{\mathrm{A}}$ \\
\hline Mean & $4.8^{b}$ & $6.2^{\mathrm{ab}}$ & $9.7^{\mathrm{a}}$ & $9.5^{\mathrm{a}}$ & \\
\hline
\end{tabular}

Means followed by the same lower-case letters in rows and upper-case letters in columns are not different by Student's $t$-test $(\mathrm{P}>0.05)$. Mean standard errors: period=1.1; grazing height=1.1. Dates: $\mathrm{P} 1(02 / 02 / 2010$ 02/10/2010); P2 (03/05/2010-03/13/2010). 
The leaf elongation rate (LER) was affected by the evaluation period $(\mathrm{P}<0.0001)$, grazing height $(\mathrm{P}<0.0001)$, and the interaction between these factors $(\mathrm{P}=0.0021)$; higher LERs were recorded during the first evaluation period, although the $10 \mathrm{~cm}$ treatment showed no difference between the periods (Table 3). In addition, during the first evaluation period, pastures managed at $30 \mathrm{~cm}$ or more had the highest LER, although the $20 \mathrm{~cm}$ treatment was statistically equivalent (Table 3 ). These variations were mainly because of the favorable environmental conditions during the first evaluation period (Figure 1) and the concomitant increase in LAI as a function of grazing heights (discussed below, Table 9). It is worth mentioning that the high LER values, which may be a result of the greater availability of nutrients commonly observed in ICLS ${ }^{(11-12)}$

Table 3. Leaf elongation rate ( $\mathrm{cm} /$ tiller/day) of Alexandergrass pastures maintained at four grazing heights $(10,20,30$, or $40 \mathrm{~cm})$ by continuous stocking method.

\begin{tabular}{|c|c|c|c|c|c|}
\hline \multirow{2}{*}{ Period } & \multicolumn{4}{|c|}{ Grazing height $(\mathrm{cm})$} & \multirow{2}{*}{ Mean } \\
\hline & 10 & 20 & 30 & 40 & \\
\hline 1 & $0.99 \mathrm{Ac}$ & $1.87^{\mathrm{Ab}}$ & $2.48^{\mathrm{Aab}}$ & $2.93^{\mathrm{Aa}}$ & 2.07 \\
\hline 2 & $0.75^{\mathrm{Aa}}$ & $0.96^{\mathrm{Ba}}$ & $0.96^{\mathrm{Ba}}$ & $1.19^{\mathrm{Ba}}$ & 0.97 \\
\hline Mean & 0.87 & 1.41 & 1.72 & 2.06 & \\
\hline
\end{tabular}

Means followed by the same lower-case letters in rows and upper-case letters in columns are not different by Student's $t$-test $(\mathrm{P}>0.05)$. Mean standard error: period*grazing height $=0.16$. Dates: P1 $(02 / 02 / 2010$ 02/10/2010); P2 (03/05/2010-03/13/2010).

Leaf lifespan is an important feature in determining tissue flows for individual tillers ${ }^{(13)}$. In our experiment, it was affected by the evaluation period $(\mathrm{P}<0.0001)$, grazing height $(\mathrm{P}<0.0001)$, and the evaluation period* grazing height interaction $(\mathrm{P}=0.0502)$, with the highest values being registered for the 30 and $40 \mathrm{~cm}$ treatments, mainly during the second period (Table 4). In theory, having long-lived leaves could be an advantage, because it increases the probability of being harvested. However, our result reflects the levels of forage accumulation rates (described below, Table 10) and the stocking rates (Figure 2) utilized to maintain grazing heights. In this sense, in order to maintain higher grazing heights, a lower stocking rate was necessary (particularly during the second period), thus reducing the frequency of defoliation of individual tillers ${ }^{(13)}$ and increasing leaf lifespan.

Table 4. Leaf lifespan (days) of Alexandergrass pastures maintained at four grazing heights $(10,20,30$, or $40 \mathrm{~cm})$ by continuous stocking method.

\begin{tabular}{|c|c|c|c|c|c|}
\hline \multirow{2}{*}{ Period } & \multicolumn{4}{|c|}{ Grazing height $(\mathrm{cm})$} & \multirow{2}{*}{ Mean } \\
\hline & 10 & 20 & 30 & 40 & \\
\hline 1 & $11.7^{\mathrm{Aa}}$ & $18.8^{\mathrm{Bb}}$ & $31.6^{\mathrm{Ba}}$ & $33.3^{\mathrm{Ba}}$ & 23.9 \\
\hline 2 & $18.2^{\mathrm{Bb}}$ & $32.8^{\mathrm{Ab}}$ & $62.2^{\mathrm{Aa}}$ & $67.2^{\mathrm{Aa}}$ & 46.1 \\
\hline Mean & 15.0 & 25.8 & 48.9 & 50.2 & \\
\hline
\end{tabular}

Means followed by the same lower-case letters in rows and upper-case letters in columns are not different by Student's $t$-test $(\mathrm{P}>0.05)$. Mean standard error: period*grazing height $=5.5$. Dates: P1 $(02 / 02 / 2010-$ 02/10/2010); P2 (03/05/2010-03/13/2010).

Although undesirable, senescence is an unavoidable process, so grazing management should be oriented towards its reduction or control. In our study, leaf senescence rate (LSR) varied only according to grazing height $(\mathrm{P}=0.0060)$, with no effects of evaluation period $(\mathrm{P}=0.4074)$ or the period*grazing height interaction $(\mathrm{P}=0.5942)$; LSR increased according to grazing height increments, although there was an equivalence between some treatments (Table 5). These results are a 
consequence of the greater amount of mature tissues present at taller grazing heights, which increases the LSR by both: i) reducing the penetration of light into the sward canopy; and ii) reaching their lifespan. In addition, as mentioned previously, pastures maintained at higher grazing heights show a lower frequency of defoliation, so a greater amount of leaves can reach their leaf lifespan and senesce $^{(13)}$.

Table 5. Leaf senescence rate $(\mathrm{cm} /$ tiller/day) of Alexandergrass pastures maintained at four grazing heights $(10,20,30$, or $40 \mathrm{~cm})$ by continuous stocking method.

\begin{tabular}{|c|c|c|c|c|c|}
\hline \multirow{2}{*}{ Period } & \multicolumn{4}{|c|}{ Grazing height $(\mathrm{cm})$} & \multirow{2}{*}{ Mean } \\
\hline & 10 & 20 & 30 & 40 & \\
\hline 1 & 0.11 & 0.52 & 0.60 & 0.90 & 0,53 \\
\hline 2 & 0.24 & 0.39 & 0.51 & 0.64 & 0,45 \\
\hline Mean & $0.17^{b}$ & $0.46^{\mathrm{ab}}$ & $0.55^{\mathrm{ab}}$ & $0.75^{\mathrm{a}}$ & \\
\hline
\end{tabular}

Means followed by the same lower-case letters in rows are not different by Student's $t$-test $(P>0.05)$. Mean standard error: grazing height=0.1. Dates: P1 (02/02/2010-02/10/2010); P2 (03/05/2010-03/13/2010).

Usually, the number of live leaves per tiller (NGL) is fairly constant for a given genotype ${ }^{(14-15)}$, but grazing management practices can change it. The NGL was only affected by grazing heights ( $\mathrm{P}<0.0001)$, increasing according to grazing height increments (Table 6). It is interesting to note the plateau of approximately 4.5 leaves at heights of $30 \mathrm{~cm}$ or greater, indicating that this may be the upper limit for Alexandergrass swards. The number of growing leaves per tiller was not affected by the treatments or evaluation periods $(\mathrm{P}>0.05)$, showing an average value of 1.5 growing leaves/tiller. Such a result suggests that the number of growing leaves in Alexandergrass tillers is fairly constant, with LER being the main process that can be modified by grazing management strategies for the improvement of forage production.

Table 6. Number of live leaves per tiller (leaves/tiller) of Alexandergrass pastures maintained at four grazing heights $(10,20,30$, or $40 \mathrm{~cm})$ by continuous stocking method.

\begin{tabular}{|c|c|c|c|c|c|}
\hline \multirow{2}{*}{ Period } & \multicolumn{4}{|c|}{ Grazing height (cm) } & \multirow{2}{*}{ Mean } \\
\hline & 10 & 20 & 30 & 40 & \\
\hline 1 & 2.6 & 3.5 & 4.1 & 4.5 & 3.7 \\
\hline 2 & 3.0 & 3.7 & 4.3 & 4.6 & 3.9 \\
\hline Mean & $2.8^{\mathrm{c}}$ & $3.6^{b}$ & $4.2^{\mathrm{ab}}$ & $4.6^{\mathrm{a}}$ & \\
\hline
\end{tabular}

Means followed by the same lower-case letters in rows are not different by Student's $t$-test $(\mathrm{P}>0.05)$. Mean standard error: grazing height=0.16. Dates: P1 (02/02/2010-02/10/2010); P2 (03/05/2010-03/13/2010).

Tiller population density (TPD) is one of the main LAI components, with great flexibility shown by plants $^{(3)}$. In our experiment, TPD was influenced by grazing height $(\mathrm{P}<0.0001)$ and evaluation period $(\mathrm{P}=0.0043)$, with no interaction between them $(\mathrm{P}=0.1738)$. Regardless of grazing height, the higher TPD values were recorded during the first period (Table 7). This difference is probably due to shading and the preferential allocation of assimilates to reproductive tillers, which is commonly observed at the end of the vegetative/beginning of the reproductive stage ${ }^{(3)}$. Regardless of the evaluation period, the highest values were recorded on swards maintained at $10 \mathrm{~cm}$, and the lowest on those maintained at $40 \mathrm{~cm}$ (Table 7). Because TPD is influenced by the quantity and quality of light that reaches the axillary and basilar meristems, the lower the grazing height, the higher the TPD (composed mainly of small tillers), as a greater quantity and quality of light reaches the bottom of the sward canopy ${ }^{(3,8)}$. 
Table 7. Tiller population density (tiller $/ \mathrm{m}^{2}$ ) of Alexandergrass pastures maintained at four grazing heights $(10,20,30$, or $40 \mathrm{~cm})$ by continuous stocking method.

\begin{tabular}{|c|c|c|c|c|c|}
\hline \multirow{2}{*}{ Period } & \multicolumn{4}{|c|}{ Grazing height $(\mathrm{cm})$} & \multirow{2}{*}{ Mean } \\
\hline & 10 & 20 & 30 & 40 & \\
\hline 1 & 1049 & 639 & 619 & 435 & 652 \\
\hline 2 & 990 & 550 & 332 & 269 & 470 \\
\hline Mean & $1018^{a}$ & $592^{\circ}$ & $453^{b c}$ & $342^{c}$ & \\
\hline
\end{tabular}

Means followed by the same lower-case letters in rows are not different by Student's $t$-test $(\mathrm{P}>0.05)$. Mean standard error: grazing height=10.1. Dates: P1 (02/02/2010-02/10/2010); P2 (03/05/2010-03/13/2010).

Leaf lamina length (LLL) varied according to the evaluation period $(\mathrm{P}=0.0074)$ and the grazing height $(\mathrm{P}<0.0001)$, but there was no interaction between them $(\mathrm{P}=0.2461)$; greater values were observed during the first evaluation period and at taller grazing heights (Table 8). The LLL is determined by the LAR and the LER, as the growth interval is a function of the appearance of successive leaves ${ }^{(14)}$. As the LER range according to grazing heights was of a greater magnitude than the LAR (Table 1 and Table 3), the higher LLL can be explained by the higher LER observed in such situations. This relationship also explains the differences detected between evaluation periods (Table 8), as the lower values of LAR (Table 1) and LER (Table 3) were detected during the second period. Finally, the higher stocking density necessary to keep grazing heights lower (previously mentioned), may have contributed to the lower values of LLL, as it implies a greater frequency of defoliation of individual tillers $^{(13)}$.

Table 8. Mean leaf lamina length ( $\mathrm{cm} /$ leaf) of Alexandergrass pastures maintained at four grazing heights $(10,20,30$, or $40 \mathrm{~cm})$ by continuous stocking method.

\begin{tabular}{|c|c|c|c|c|c|}
\hline \multirow{2}{*}{ Period } & \multicolumn{4}{|c|}{ Grazing height $(\mathrm{cm})$} & \multirow{2}{*}{ Mean } \\
\hline & 10 & 20 & 30 & 40 & \\
\hline 1 & 4.1 & 9.2 & 16.6 & 20.0 & $12.5^{\mathrm{A}}$ \\
\hline 2 & 4.2 & 7.4 & 12.7 & 16.0 & $10.1^{B}$ \\
\hline Mean & $4.1^{d}$ & $8.3^{\circ}$ & $14.7^{\circ}$ & $18.0^{\mathrm{a}}$ & \\
\hline
\end{tabular}

Means followed by the same lower-case letters in rows and upper-case letters in columns are not different by Student's $t$-test $(\mathrm{P}>0.05)$. Mean standard errors: grazing height $=0.76$; period $=0.54$. Dates: $\mathrm{P} 1$ (02/02/2010-02/10/2010); P2 (03/05/2010-03/13/2010).

Leaf area index (LAI) was affected by grazing height $(\mathrm{P}=0.0001)$ and evaluation period $(\mathrm{P}=0.0164)$, but there was no interaction between these factors $(\mathrm{P}=0.1069)$; pastures managed at a height of 30 $40 \mathrm{~cm}$ had the highest values and were similar to each other (Table 9). In addition, the highest value was observed during the first evaluation period (Table 9). In fact, pastures managed under the continuous stocking method may present an equivalent LAI within a range of grazing management targets (e.g., height and forage mass), as a consequence of the compensatory mechanisms between tiller size/population density ${ }^{(8,15)}$ and tiller size/tissue flow ${ }^{(4-5)}$. In addition, the LAI can be maximized under favorable growth conditions (e.g., light, and rainfall).

The forage accumulation rate $(\mathrm{FAR})$ varied with grazing height $(\mathrm{P}=0.0011)$ and the evaluation period $(\mathrm{P}=0.0068)$, but there was no interaction between them $(\mathrm{P}=0.5957)$. Similar to LAI, pastures maintained between 30 and $40 \mathrm{~cm}$ were superior and similar to each other, and, regardless of the grazing height, the greatest values were observed during the first evaluation period (Table 10). From 
an ecological point of view, the LAI is the most important canopy characteristic, as it determines the levels of light interception, gas and water exchange, and both within- and below-canopy microclimates, been a key component of biogeochemical cycles in ecosystems ${ }^{(16)}$. Therefore, any modification in LAI (whether related to pasture management or not) is accompanied by a change in forage yield. In fact, in our experiment, the LAI could explain approximately $51 \%$ of the FAR variation (Figure 3). Thus, the variations in FAR reported here are mainly related to variations in LAI.

Table 9. Leaf area index (LAI) of Alexandergrass pastures maintained at four grazing heights $(10,20,30$, or $40 \mathrm{~cm})$ by continuous stocking method.

\begin{tabular}{|c|c|c|c|c|c|}
\hline \multirow{2}{*}{ Period } & \multicolumn{4}{|c|}{ Grazing height (cm) } & \multirow{2}{*}{ Mean } \\
\hline & 10 & 20 & 30 & 40 & \\
\hline 1 & 0.67 & 1.37 & 3.47 & 2.77 & $2,07 \mathrm{~A}$ \\
\hline 2 & 0.87 & 1.03 & 1.97 & 1.83 & $1,42^{\mathrm{B}}$ \\
\hline Mean & $0.77^{b}$ & $1.20^{b}$ & $2.71^{\mathrm{a}}$ & $2.30^{\mathrm{a}}$ & \\
\hline
\end{tabular}

Means followed by the same lower-case letters in rows and upper-case letters in columns are not different by Student's $t$-test $(\mathrm{P}>0.05)$. Mean standard errors: grazing height $=0.23$; period $=0.16$. Dates: $\mathrm{P} 1$ (02/02/2010-02/10/2010); P2 (03/05/2010-03/13/2010).

Table 10. Forage accumulation rate $(\mathrm{kg} \mathrm{DM} / \mathrm{ha} /$ day) of Alexandergrass pastures maintained at four grazing heights $(10,20,30$, or $40 \mathrm{~cm})$ by continuous stocking method.

\begin{tabular}{|c|c|c|c|c|c|}
\hline \multirow{2}{*}{ Period } & \multicolumn{4}{|c|}{ Grazing height (cm) } & \multirow{2}{*}{ Mean } \\
\hline & 10 & 20 & 30 & 40 & \\
\hline 1 & 76.8 & 117.7 & 166.6 & 188.7 & $137.5^{\mathrm{A}}$ \\
\hline 2 & 56.0 & 87.3 & 121.4 & 119.5 & $96.0^{\mathrm{B}}$ \\
\hline Mean & $66.4^{c}$ & $102.5^{b}$ & $144.0^{\mathrm{a}}$ & $154.1^{\mathrm{a}}$ & \\
\hline
\end{tabular}

Means followed by the same lower-case letters in rows and upper-case letters in columns are not different by Student's $t$-test $(\mathrm{P}>0.05)$. Mean standard errors: grazing height $=9.24$; period $=13.08$. Dates: $\mathrm{P} 1$ (02/02/2010-02/10/2010); P2 (03/05/2010-03/13/2010).

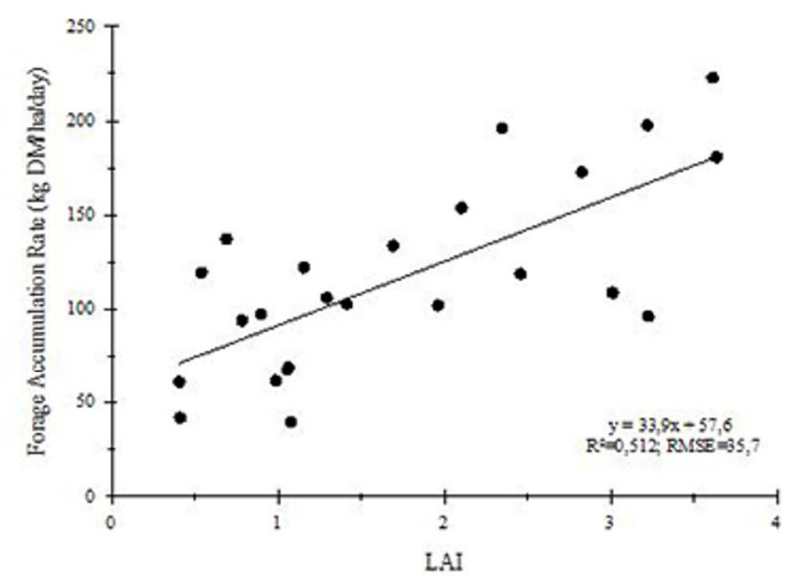

Figure 3. Relationship between leaf area index (LAI) and forage accumulation rate (FAR) observed in Alexandergrass pastures maintained at four grazing heights (10, 20, 30 , or $40 \mathrm{~cm}$ ) by continuous stocking method. 


\section{Conclusion}

Grazing height modifies the morphogenetic and structural responses of Alexandergrass swards under the continuous stocking method, enabling similar forage accumulation within a range of grazing height targets. Therefore, it is recommended that Alexandergrass pastures that are under continuous stocking should be maintained at a height of at least $30 \mathrm{~cm}$ when the objective is to maximize forage production.

\section{References}

1. Adami PF, Soares AB, Assmann TS, Assmann AL, Sartor LR, Pitta CSR, Franchin MF, Migliorini F. Dynamic of a papuã pasture under two grazing intensities and two nitrogen levels. R. Bras. Zootec. 2010; 39(12): 2569-2577. http://www.scielo.br/pdf/rbz/v39n12/a03v39n12.pdf

2. Da Silva SC, Nascimento Jr. D. Avanços na pesquisa com plantas forrageiras tropicais em pastagens: características morfofisiológicas e manejo do pastejo. R. Bras. Zootec. 2007; 36(supl.): 121-138 http://www.scielo.br/pdf/rbz/v36s0/14.pdf

3. Da Silva SC, Sbrissia AF, Pereira LET. Ecophysiology of C4 forage grasses - Understanding plant growth for optimising their use and management. Agriculture. 2015; 5(3): 598 - 625. http://www.mdpi.com/2077$0472 / 5 / 3 / 598$

4. Bircham JS, Hodgson J. The influence of sward condition on rates of herbage growth and senescence in mixed swards under continuous stocking management. Grass Forage Sci. 1983; 38(4): 323 - 331. http://onlinelibrary.wiley.com/doi/10.1111/j.1365-2494.1983.tb01656.x/abstract

5. Parsons AJ, Johnson IR, Harvey A. Use of a model to optimize the interaction between frequency and severity of intermittent defoliation and to provide a fundamental comparison of the continuous and intermittent defoliation of grass. Grass Forage Sci. 1988; 43(1): 49 - 59. http://onlinelibrary.wiley.com/doi/10.1111/j.13652494.1988.tb02140.x/abstract

6. EMBRAPA - Centro Nacional de Pesquisa de Solos. Sistema brasileiro de classificação de solos. 2 ed. Rio de Janeiro: Embrapa-SPI; 2006. 306 p.

7. CQFS - Comissão de química e fertilidade do solo. 2004. Manual de adubação e calagem para os estados do Rio Grande do Sul e de Santa Catarina, 10 ed. SBCS, Porto Alegre.

8. Sbrissia AF, Da Silva SC. Compensação tamanho:densidade populacional de perfilhos em pastos de capimmarandu. R. Bras. Zootec. 2008; 37(1): 35-47. http://www.scielo.br/pdf/rbz/v37n1/v37n1a05.pdf

9. Carrère P, Louault F, Soussana JF. Tissue turnover within grass-clover mixed swards grazed by sheep. Methodology for calculating growth, senescence and intake fluxes. J. Appl. Ecol. 1997; 34(2): 333-348. http://www.jstor.org/stable/2404880

10. Duru M, Ducrocq H. Growth and senescence of the successive leaves on a Cocksfoot tiller. Effect of nitrogen and cutting regime. Ann. Bot. 2000; 85(5):645-653. https://academic.oup.com/aob/article/85/5/645/2588180

11. Moraes A, Carvalho PCF, Lustosa SBC, Lang CR, Deiss L. Research on integrated crop-livestock systems in Brazil. Rev. Ciênc. Agron. 2014; 45(5): 1024-1031. http://www.scielo.br/pdf/rca/v45n5spe/18.pdf

12. Salton JC, Mercante FM, Tomazi M, Zanatta JA, Concenço G, Silva WM, Retore M. Integrated croplivestock system in tropical Brazil: Toward a sustainable production system. Agric. Ecosyst. Environ. 2014; 190(June): 70-79. https://www.sciencedirect.com/science/article/pii/S0167880913003332

13. Lemaire GL, Da Silva SC, Agnusdei M, Wade M, Hodgson J. Interactions between leaf lifespan and defoliation in temperate and tropical pastures: a review. Grass Forage Sci. 2009; 64(4): 341-353. https://onlinelibrary.wiley.com/doi/epdf/10.1111/j.1365-2494.2009.00707.x 
14. Lemaire G, Chapman, DF. Tissue fluxes in grazing plant communities. In: Hodgson J, Illius AW (eds). The Ecology and Management of Grazing Systems. Wallingford, UK:CAB International; 1996; p. 3-36.

15. Matthew C, Lemaire G, Sackville Halmilton NR, Hernádez-Garay A. A modified self-thinning equation to describe size/density relationships for defoliated swards. Ann. Bot. 1995; 76(6):579-587. https://academic.oup.com/aob/article-abstract/76/6/579/207994?redirectedFrom=fulltext

16. Breda NJJ. Ground-based measurements of leaf area index: a review of methods, instruments and current $\begin{array}{llllll}\text { controversies. } & \text { J. } & \text { Exp. } & \text { Bot. } & \text { 2003; } & \text { 54(392): }\end{array}$ https://academic.oup.com/jxb/article/54/392/2403/621920 